\title{
Cultural Representation in Wole Soyinka's The Lion and The Jewel
}

\section{OPEN ACCESS}

Manuscript ID:

ENG-2021-09044228

Volume: 9

Issue: 4

Month: September

Year: 2021

P-ISSN: 2320-2645

E-ISSN: 2582-3531

Received: 21.07.2021

Accepted: 24.08.2021

Published: 01.09.2021

Citation:

Showmya, R., and R. Sinega. "Cultural Representation in Wole Soyinka's The Lion and The Jewel." Shanlax International Journal of English, vol. 9, no. 4, 2021, pp. 41-44.

DOI:

https://doi.org/10.34293/ english.v9i4.4228

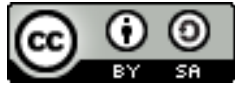

This work is licensed under a Creative Commons Attribution-ShareAlike 4.0 International License

\author{
R. Showmya \\ S.B.G. College of Education, Tiruchirappalli, Tamil Nadu, India \\ https://orcid.org/0000-0002-4457-9347

\section{R. Sinega} \\ Cauvery College for Women (Autonomous), Tiruchirappalli, Tamil Nadu, India \\ https://orcid.org/0000-0003-1432-2521
}

\begin{abstract}
This article attempts to pinpoint the interaction of Cultural Representation in Wole Soyinka's play The Lion and the Jewel. Culture can be perceived as a bunch of regular convictions that hold individuals together, these normal convictions lead to social practices, and practices that are instilled with significance. Culture is to incorporate every one of the aspects of human experience that stretch out past our actual truth, culture alludes how we comprehend ourselves both as people and as member of the society incorporates stories, religion, media, ceremonies, and even language.The Europeans colonization in African made many changes in their culture, some people thought that they are reformed by the European, but some thought that their culture was changed by them. The play sets in the village named Ilujinle in West Africa, and it has the characteristics like comedy, love, myth, folklore, dance, music, and cultural conflict between old culture and new culture, because the old culture was followed by uneducated people, they were led by Baroka and the new culture was followed by Lakunle, who works as a teacher in that village. Wole Soyinka presents the custom and traditions of Yoruba in the play The Lion and the Jewel and he created significant characters, who defends the modernity because they are deeply rooted with old custom and tradition of their culture.
\end{abstract}

Keywords: Yoruba culture, Bride price, The Lion and the Jewel, Wole Soyinka, Polygamous society, Beliefs in Gods

\section{Introduction}

Culture is the frameworks of information shared by a moderately huge gathering of individuals, it is the broadest sense that developed conduct; that is the entirety of an individual's learned, amassed experience which is socially communicated, or all the more momentarily, conduct through friendly learning and it is a lifestyle of a gathering of individuals that is their practice, convictions, qualities, and images that they acknowledge for the most part without pondering them and they are passed along by correspondence and impersonation starting with age one then to the next. "Culture is said to embody the best that has 'been thought and said' in a society. It is the sum of the great ideas, as represented in the classic works of literature, painting, music and philosophy-the 'high culture' of an age.'(Hall, 02)

Wole Soyinka, his full name is Akinwande Oluwole Soyinka. He was born on 13 July, 1934 in Nigeria, he received Nobel Prize for Literature in 1986 and he was the first African writer to hold this honour. He was a Nigerian playwright and political activist, who mentioned about West Africa in satirical notes in his writings and he worked for a long period in order to get Nigerian democracy. 
Wole Soyinka'sfirst playis A Dance of the Forests, published in 1963 for the Nigerian Independence celebration, his other plays include The Lion and the Jewel, which was published in 1963, in which he mentioned about Westernized schoolteachers. Wole Soyinka wrote one autobiographical work, Ake: The Years of Childhood was published in 1981.

The play The Lion and the Jewel is divided into three parts-Morning, Noon, and Night, it begins with Sidi, the town beauty of Ilujinle, placing the bucket of water on her head. Lakunle, the western instructed teacher, criticized for carrying a heavy load on her head and he requests Sidi to marry him, Sidi says that she is prepared to marry himhowever Lakunle must pay the bride price in full, she says it so because in Yoruba culture if a girl is married without bride price she is considered as not a virgin. Lakunle instructs her that paying Bride price is an outdated custom and it implies buying a woman as aproperty, he also says that women must be equally treated like men. The crowd of people enter to bring the information about a person who comes to the village by his motorcycle with camera and magazine, that highlights Sidi's image on the first page and this made her a celebrity, and they also mentioned that it has the picture of Baroka at the corner of the page. They started dancing to celebrate that event.

The second part Noon begins with Sadiku's information to Sidi that Baroka wants to marry her, and he has vowed to take no other spouse after her,she also says that when a woman turns into the last spouse of the Bale, when the Bale dies, that girl gets the honor of turning into a senior spouse of the new Bale. Sidi replied that shewill not marry him. Then Sadiku reached her house and informs Baroka about Sidi's refusal of his proposal, after hearing this Baroka loses his control, suddenly he made a trick and told his wife about the loss of manhood, and he asked her not to share with anyone.

The last part of the play, Night begins with Sadiku information to Sidi, suddenly Sidi gotidea to reachthe house of Barokaso that she can get a chance to mock him. The scene shifts to Baroka's bedroom, where he had friendly wresting, Sidi pretends that she came to repent, but she mocks at him. He says many things and he also induced interest by saying about stamp, then he seduced her. Lakunle and Sadiku are trusting that Sidi will return, Sidi comes out hurls herself on the ground crying and tells Sadiku that Baroka lied to her and it was a trick to get her. Finally, Lakunle finds the truth and promised to marry her without any Bride price, but Sidi rejected him by saying that she will marry only Baroka and not him and she asked the people to perform dance to celebrate her marriage with Baroka.

\section{The Cultures of Yoruba People}

The Western-style of dressing can be seen with Lakunle, who wears a ragged and messed clean English suit that is excessively little for him, and he wears a tie that vanishes underneath his petticoat. His pants are incredibly larger than average, and his shoes are Blanco-white. Wole Soyinka satirized the western people's thoughts with him, Lakunle misunderstood a portion of the books and he accepts to be valid. For instance, he is wrong by saying female's mind is smaller than men's mind.

LAKUNLE. It's in my books,

Women have a smaller brain than men

That's why they are called the weaker sex. (6)

Bride Price, is in the culture of Yoruba people to ask for bride price before giving the female children to a man in marriage, this can be noted with the conversation of Sidi and Lakunle, he loves Sidi and plans to marry her however he cannot because she requested him to pay the customary bride price.And she also mentioned that if she did not get the Bride Price means people say she is not a virgin. Lakunle refused to pay because he thinks it is an uncivilized incredible custom but Sidi does not care about his thoughts and said him that she will marry him only if he pays the Bride Price.

SIDI. I shall marry you today, next week

Or any day you name.

But my bride-price must first be paid.(8).

Polygamous society, the wedding of numerous spouses is legitimate in Nigeria and it is acknowledged that the elderly person can marry a young girl. The Yoruba culture permits a widow legacy in which a man can marry the widow, and the last wife of the Bale or head man will be the first wife of the next head man of the village, this can be noted that Sadiku 
is the last wife of Okiki (Baroka's father), and after his death, she became the first wife of new leader that is Baroka's first wife.

SADIKU. I was there what it happened to your father, the great Okiki. I did for him, I, the youngest and freshest of the wives. I killed him with my strength. I called him and he came at me, but no, for him, this was not like other times. (30)

The Yoruba culture permits the Bale or head man of the village can marry many and has conditions like treating all his wife and children equally, it can be seen through the character Baroka, has many spouses from Sadiku to his latest wife Ailatu. Even at the age of sixty-two, he has a desire to marry a young girl named Sidi, after seeing Sidi's lovely picture in a shiny magazine. The first wife has to convince and make the young girl to marry her husband this can be seen in the play when Baroka's first wife Sadiku approached Sidi for marrying her husband.

Modernism can be seen in Lakunle, he has a tendency to imitate the West, he presents the modern-day European, he tremendously entrance by the shallowest parts of the modern-day life. Lakunle dreams about the impact of modernism in their village, with the development of streets, building, and the way of life and customs of Nigeria.

LAKUNLE. This town shall see a transformation

Bride-price will be a thing forgotten... (34)

Tradition can be seen in Baroka, he maintains Yoruba culture against the western thought by his power to forestall the change of Ilujinle. Next by Sidi, who shows the ethical quality when she refuses to release the bucket of water, because the load addresses commitment to difficult work and it is the part of their culture that women must fetch and carry loads on their head. Another incident by Sidi is at the point when she lost her virginity to Baroka, Lakunle energetically acknowledges to marry her, however, she rejects to marry him.

SIDI. Marry who...? You thought...

Did you really think that you, and I...(57)

Yoruba culture has beliefs in Gods like Ogun and Sango are believed to always influence the existence of the individuals with the end goal that individuals commit to promise on the Yoruba Gods to affirm them right or wrong. Yoruba people believed that Ogun is the God of iron and Sango as the God of thunder and lightning. This can be seen in the play, when a girl declares by the God of Ogun in her discussion with Sidi to bear witness the reality with regards to the information on Sidi's photo in a western magazine. On another occasion, Sadiku also prays to the god Sango, for the rebuilding of Sidi's keenness when she expresses peculiar words, according to her Sidi offended the angry gods unknowingly.

SIDI. Is that the truth? Swear! Ask Ogun to

Strike you dead.

GIRL. Ogun strike me dead if I lie. (12)

SADIKU. May Sango restore your wits. For most surely some angry god has

taken possession of you. (22)

Songs and dance played an important role in the Yoruba culture, songs can be seen at the beginning of the play, in which Sidi and her town girls and Lakunle play out a dance for the western photographer who took the picture of Sidi and Baroka for his magazine. Thenext dance was performed by Lakunle to Sidi and Sadiku about the coming of the railroad, and of its rerouting away from the village under the control of headman. Another dance was performed by Sadiku after Baroka's statement of losing his manhood.

SIDI. I know. Let is dance of the lost Traveller.

SIDI. Who will dance the devil-horse? (13).

\section{Conclusion}

Wole Soyinka magnificently depicted the cultural representation in the play The Lion and the Jewel with his thoughts, he depicts the tradition, modernisation, songs and dance polygamy, the Bride price, and belief in God, as a Nigerian writer he wrote his way of life and custom in a fruitful way. The lifestyle of man ought to have both old and new tradition, they should regard and know the upsides of the old custom and culture without completely dismissing it.

\section{References}

Banham, Martin. Wole Soyinka, the Lion and the Jewel: A Critical View, edited by Yolande Cantu, Collings in association with the British 
Council, 1981.

Bora, Msomi. "English Play - The Lion and the Jewel." MSOMI BORA Online Education Center, 2020.

Brown, Raymound, and Wole Soyinka. Wole Soyinka's the Lion and the Jewel. Modern Press, 1992.

Erapu, Laban. Notes on Wole Soyinka's The Lion and the Jewel. Heinemann Educational Books, 1975.

Gnanasekaran, T. "Ambiguity of the Title a Study of Wole Soyinka's The Lion and the Jewel." Research Journal of English, vol. 5, no. 1, 2019, pp. 7-11.

Goodseed, Ochulor Nwaugo. "Language and Power: A Critical Discourse Analysis of Wole Soyinka's the Lion and the Jewel." Journal of English Language and Literature, vol. 10, no. 1, 2018, pp. 982-988.

Igwedibia, Adaoma. "A Relevance Theoretical Reading of Wole Soyinka's the Lion and the Jewel." International Journal of Applied Linguistics and English Literature, vol. 7, no. 5, 2018.

Kemi, Megbowon Funmilola, and Uwah Chijioke. "Polemics of Cultural Regeneration in Soyinka's The Lion and the Jewel." Journal of Social Sciences, vol. 51, no. 1-3, 2017, pp. 6-16.

Naveen Kumar, K. "Yoruba Tradition and Culture in Wole Soyinka's The Lion and the Jewel." Journal of Arts, Science \& Commerce, vol. 2, no. 3, 1970.

Hall, Stuart. Representation: Cultural Representations and Signifying Practices. Sage Publications, 1997.

Highmore, Ben. Culture. Routledge, 2015.
Maher, Nadia and Ibrahim Moawad. "A Study of Wole Soyinka's play The Lion and the Jewel in the Light of Cultures in Conflict." International Journal of English and Literature, vol. 7, 2016, pp. 179-188.

Middleton, John. Culture. Capstone Publication, 2002.

Moore, Gerald. Wole Soyinka (Modern African writers). Evans, 1978.

NaAllah, Abdul Rasheed. African Discourse in ISLAM, Oral Traditions, and Performance. Routledge, 2010.

Nasreen, M. "Cultural Conflict in Wole Soyinka's The Lion and the Jewel - A Contrapuntal Reading." Research Journal of English Language and Literature, vol. 5, no. 3, 2017, pp. 228-233.

Okpu, B.M. Wole Soyinka: A Bibliography. Libriservice, 1984.

Oloruntoba, Olatunde Albert. Africanisation and the Yoruba Cultural Re-presentation: A Critical Analysis of Selected Plays by Wole Soyinka. Tshwane University of Technology, 2015.

Sathya, G. "Cultural Aspects in Wole Soyinka's Lion and the Jewel." Language in India, vol. 18, 2018, pp. 547-552.

Soyinka, Wole. Five Plays: A Dance of the Forests, the Lion and the Jewel, the Swamp Dwellers, the Trails of Brother Jero and the Strong Breed. Oxford University Press, 1967.

"Wole Soyinka." The Britannica, 2019, www. britannica.com/biography/Wole-Soyinka

Vigilante, A. "The Lion and the Jewel Analysis." Mecana, 2020.

Wright, Derek. Wole Soyinka: Life, Work and Criticism. York Press, 1996.

\section{Author's Details}

R. Showmya, M.A., B.Ed.(Bachelor of Education in English), S.B.G. College of Education, Tiruchirappalli, Tanil Nadu, India, Email ID: crossandratulip@gmail.com.

R. Sinega, B.A English, Cauvery College for Women (Autonomous), Tiruchirappalli, Tamil Nadu, India. 